\title{
Article \\ Microdiamonds in Alkalic Dolerites from the North China Craton: FTIR and C Isotopic Characteristics
}

\author{
Yitao Cai ${ }^{1,2, *}$, Zhengqi Cao ${ }^{3, *}$, Fei Liu ${ }^{4}, \mathrm{Kan} \mathrm{Li}^{5}$, Long $\mathrm{Li}^{5}$ and Jingsui Yang ${ }^{6}$ \\ 1 Jinling Institute of Technology, College of Material Engineering, Nanjing 211169, China \\ 2 Nanjing Centre, Geological Survey, Nanjing 210016, China \\ 3 College of Resource Environment and Tourism, Hubei University of Arts and Science, \\ Xiangyang 441053, China \\ 4 Institute of Geology, China Academy of Geological Sciences, Beijing 100037, China; liufei@cags.ac.cn \\ 5 Department of Earth and Atmospheric Sciences, University of Alberta, Edmonton, AB T6H 2E3, Canada; \\ kan3@ualberta.ca (K.L.); long4@ualberta.ca (L.L.) \\ 6 School of Earth Sciences and Engineering, Nanjing University, Nanjing 210093, China; yangjsui@nju.edu.cn \\ * Correspondence: cyitao@cgs.cn (Y.C.); caozq11797@hbuas.edu.cn (Z.C.)
}

Citation: Cai, Y.; Cao, Z.; Liu, F.; Li, K.; Li, L.; Yang, J. Microdiamonds in Alkalic Dolerites from the North China Craton: FTIR and C Isotopic Characteristics. Crystals 2021, 11, 1325. https://doi.org/10.3390/

cryst11111325

Academic Editor: Francesco Capitelli

Received: 28 September 2021

Accepted: 28 October 2021

Published: 29 October 2021

Publisher's Note: MDPI stays neutral with regard to jurisdictional claims in published maps and institutional affiliations.

\begin{abstract}
Most of the diamond deposits in China are in the North China Craton. In addition to gem diamonds in kimberlite, a large number of microdiamonds have also been discovered in alkaline dolerites. These microdiamonds show very different characteristics from those recovered in kimberlite. Here, we report the morphology, colour, nitrogen contents, and carbon isotopic compositions of the diamonds recovered from the alkalic dolerites in eastern China. The microdiamonds are mainly cube and rhombic dodecahedron with diameters of 0.2 to $0.6 \mathrm{~mm}$. Infrared spectrum analysis shows that these microdiamonds are mostly type $\mathrm{Ib}$ with a small amount of type Ia. The $\mathrm{Y}$ centre is obvious in type $\mathrm{Ib}$ diamond. Modelling mantle residence times for the IaAB diamonds is about $550 \mathrm{Ma}$. Nitrogen contents of the diamonds range from 4.5-503 ppm, with a median value of $173 \mathrm{ppm}$. The total $\delta^{13} \mathrm{C}$ range of the microdiamonds varies between -18.6 and $-21.1 \%$ and are similar to those of ophiolite diamond.
\end{abstract}

Keywords: microdiamond; FTIR; carbon isotopic; alkalic dolerite; North China Craton

\section{Introduction}

Diamonds on the Earth mainly occur in volcanic rocks such as kimberlites and lamproites [1-8], but can also be found in ultrahigh-pressure metamorphic rocks $[9,10]$, meteorites [11] and alluvial deposits [12]. In recent years, diamonds have been recovered from ophiolites [13-16] and alkalic dolerites [17,18]. The discovery of ophiolitic diamonds and alkalic dolerites diamonds has drawn significant research interests to explore the origin of this new class of diamond source and to infer the evolution of their hosting rocks [19-21]. This new type of diamond had been initially considered as a result of contamination. However, more and more evidence either directly or indirectly demonstrates that these diamonds are of natural origin [16,18,19,22-24].

During a geological survey from 2012 to 2015, the geologist from Nanjing Centre of China Geological Survey discovered a large number of yellow microdiamonds in the Langan area in northern Anhui Province [18,25-29]. The diamond-bearing rocks of these microdiamonds mainly include dolerite and olivine basalt. From 2016 to 2018, four microdiamonds in basic rocks were recovered again in the prospecting work for primary diamond deposits in the Tashan and Zhangji areas in Xuzhou, which is geographically close to Langan [30]. All these diamonds are similar in colour and shape to ophiolite type diamonds [31] and show different characteristics of kimberlite and lamproite diamonds.

Cai et al. (2019) reported the petrological characteristics of the diamondiferous rocks $[17,21,30]$. In this paper, the morphology, infrared spectrum, and carbon isotope compositions of microdiamonds were analysed and discussed by Fourier infrared spectroscopy 
and carbon isotope test. The types of microdiamonds found in the North China Craton, the age of mantle occurrence, and the source of carbon isotopes were revealed.

\section{Geological Background and Samples}

The North China Craton (NCC) is one of the oldest cratons on Earth [32-34]. It was amalgamated after the collision of Eastern Block and Western Block at ca. 1.8 Ga, which resulted in the intervening Central Orogenic Belt [34]. The basement of the NCC mainly consists of Archean to Paleoproterozoic TTG (tonalitic-trondhjemite-granodioritic) gneisses that are covered by Mesoproterozoic to Paleozoic sediments. The basement rocks in the study area are composed of the Archaean Wuhe Group and the Paleoproterozoic Fengyang Group and are overlined by the Proterozoic and Lower-Paleozoic cover rocks, including dolomite, limestone, shale, and sandstone. Voluminous Mesozoic magmatic rocks including diabase, basalts, quartz syenite porphyries, and spessartites occur in the area [28].

Several diamond deposits have been reported in the North China Craton $[33,35]$. The two most significant deposits are in Wafangdian of Liaoning province and Mengyin of Shandong Province [1]. They are distributed on both sides of the Tanlu fault-the Wafangdian diamond ore area lies in the east and the Mengyin diamond ore area lies in the west. Moreover, many microdiamonds have been found in the western side of the Tanlu fault and the southern margin of the NCC, such as those in the northern Jiangsu and Anhui provinces. The area where AD microdiamonds (microdiamonds from alkalic dolerites) were found is located in the southeast margin of the NCC and west of the Tanlu fault.

Diamonds in basaltic rocks mostly coexist with high-pressure minerals such as pyrope and hessonite $[25,26,28]$. The AD microdiamonds obtained in this study are cube and rhombic dodecahedron with diameters of 0.2 to $0.6 \mathrm{~mm}$. These microdiamonds are colourless to yellowish (Figure 1a-c) [30]. Microscopic observations revealed irregularly shaped black to light-coloured mineral inclusions. High pressure minerals were also observed in these microdiamonds. More detailed mineralogical characterization will be reported in a separate paper. The surface characteristics of diamonds, such as dissolution, can be observed on relatively large microdiamonds (Figure 1d) [30]. The characteristics of diamonds are summarized in Table 1.

Table 1. Characteristic of the tested Diamonds.

\begin{tabular}{|c|c|c|c|}
\hline Sample No. & Color & Shape & Surface Character \\
\hline AD1 & yellow & cubo-octahedral & Shallow depressions \\
\hline AD2 & Light yellow & $\begin{array}{c}\text { Rounded } \\
\text { Dodecahedra }\end{array}$ & $\begin{array}{l}\text { Stacked growth layers, } \\
\text { plastic deformation lines, } \\
\text { terraces, elongate hillocks }\end{array}$ \\
\hline AD3 & colorless & fragment & Stacked growth layers, \\
\hline AD4 & yellow & cubo-octahedral & Stacked growth layers, \\
\hline AD5 & yellow & cubo-octahedral & Stacked growth layers, \\
\hline AD6 & yellow & cubo-octahedral & \\
\hline AD7 & yellow & cubo-octahedral & \\
\hline AD8 & yellow & cubo-octahedral & Shallow depressions, \\
\hline AD9 & yellow & cubo-octahedral & \\
\hline AD10 & yellow & cubo-octahedral & \\
\hline
\end{tabular}




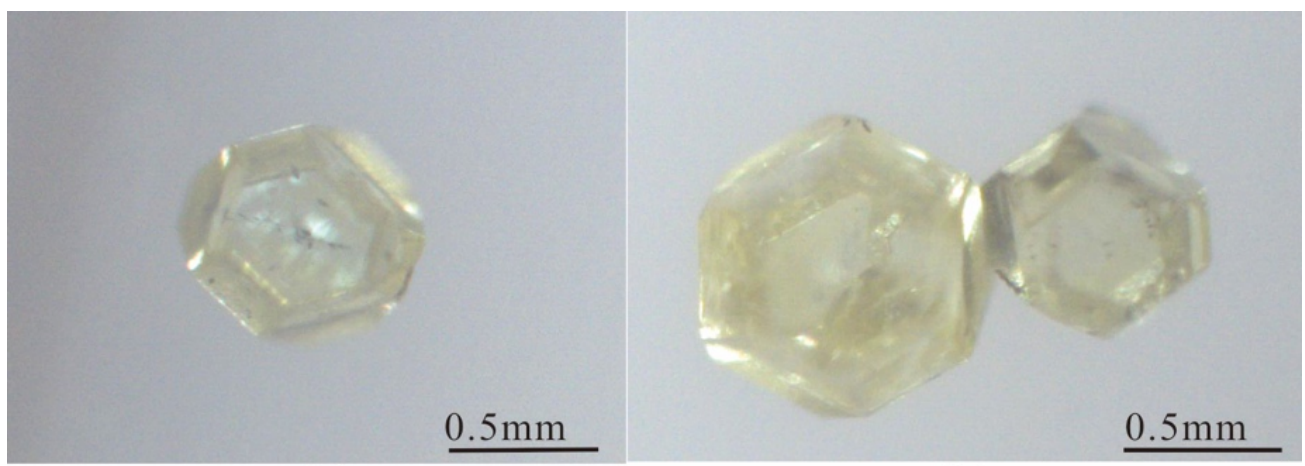

(a)

(b)

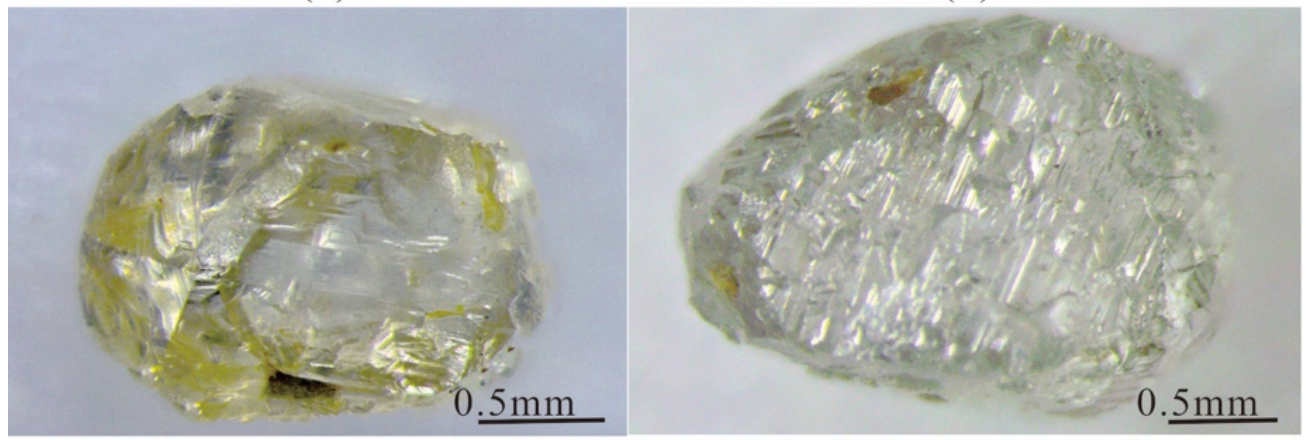

(c)

(d)

Figure 1. (a) Ib type AD microdiamond; (b) IaA/Ib type AD microdiamonds; (c) IaAB type AD microdiamond; (d) IaA type AD microdiamond.

\section{Analytical Method}

\subsection{Fourier Transform Infrared Spectroscopy}

Infrared absorption spectra were collected using Bruker Vertex80 (Second Institute of Oceanography, MNR) and Thermo Fisher Nicolet Nexus 470 (University of Alberta) FTIR spectrometer, equipped with a Continuum IR microscope with a motorized stage. A midinfrared light source was used to collect spectra with a spectral range of $4000-650 \mathrm{~cm}^{-1}$. Diamonds were placed on a KBr plane and measured under $20 \times$ magnification infrared objective in transmission mode. Spectra were acquired by averaging 200 scans at a spectral resolution of $1 \mathrm{~cm}^{-1}$ with an aperture size of $100 \times 100 \mu \mathrm{m}$. Baseline corrected spectra were normalized to $1 \mathrm{~cm}$ sample thickness employing an absorption coefficient of $11.94 \mathrm{~cm}^{-1}$ for the intrinsic absorption of a diamond at $1995 \mathrm{~cm}^{-1}$ [36,37].

\subsection{Carbon Isotopic Composition}

Carbon isotopic compositions were measured at the University of Alberta. Diamond grains weighing 129-314 ug were weighed and wrapped into a tin capsule, which was then loaded and combusted in an Elemental Analyzer (Thermal Flash 2000) at $1050{ }^{\circ} \mathrm{C}$. The produced $\mathrm{CO}_{2}$ was carried by a high-purity helium stream to an isotope ratio mass spectrometer (Thermo Delta V Plus) for isotopic measurement. Diamonds are resistant to combustion and complete combustion generally required multiple burning. Cumulative $\mathrm{CO}_{2}$ yields of $100 \%$ were normally achieved after 3-4 burns. $\mathrm{CO}_{2}$ gas from each burn was measured for $\delta^{13} \mathrm{C}$ value unless the amount of $\mathrm{CO}_{2}$ gas in the last burn was too low to give reliable data. The $\delta^{13} \mathrm{C}$ reproducibility of all the burns from individual diamonds was better than $0.3 \%$. A weighted average $\delta^{13} \mathrm{C}$ value of all the burns was used to represent the value of each diamond. $\mathrm{CO}_{2}$ blanks were carefully monitored between samples to ensure no memory effect. The low-organic content soil standard (reference values: $\mathrm{C}=1.61 \mathrm{wt} \%$; $\delta^{13} \mathrm{C}_{\mathrm{V}-\mathrm{PDB}}=-26.66 \%$ ) and high-organic content sediment standard (reference values: $\mathrm{C}=7.45 \mathrm{wt} \% ; \delta^{13} \mathrm{C}_{\mathrm{V}-\mathrm{PDB}}=-28.85 \%$ ) were measured in parallel to samples and used to 
calibrate the carbon yield and isotopic ratios of samples. Repeated analysis of the standards gave a 2 standard deviation better than $0.2 \%$.

\section{Analysis Result}

\subsection{Fourier Transform Infrared Spectroscopy}

Infrared spectral data of ten samples were obtained and fitted by the OMNIC software. The DiaMap software (DiaMap_CABX 17_11_07 version) was used for spectrum analysis and $\mathrm{N}$ content calculation [37-40]. The concentration of $C$ centres (in at. ppm) was calculated by multiplying the absorption coefficient at $1344 \mathrm{~cm}^{-1}$ by a factor of 37 [41,42].

Microdiamonds exhibit a broad range of $\mathrm{N}$ concentration from 4.5-503 ppm, with a median value of $173 \mathrm{ppm}$. Eight diamonds exhibit intense $\mathrm{N}$ absorption, and $\mathrm{C}$ centres were found at $1344 \mathrm{~cm}^{-1}$ in these diamonds. Three diamonds that contain $\mathrm{N}$ predominantly in the form of A centres also show a discernible $C$ centre line at $1344 \mathrm{~cm}^{-1}$; these diamonds are classified and referred to as Type Ia/Ib hereafter (Table 2). Bands or lines corresponding to $\mathrm{B}, \mathrm{B}^{\prime}$ and $\mathrm{A}$ centres were found co-existing in two diamonds.

Table 2. Types of tested microdiamonds and the data of the IR spectrums.

\begin{tabular}{|c|c|c|c|c|c|}
\hline Sample No. & Major Peak $\left(\mathrm{cm}^{-1}\right)$ & Type of C-N & Type & N Concentration $\left(10^{-6}\right)$ & $N_{\text {total }}\left(10^{-6}\right)$ \\
\hline AD1 & $1280,1344,1976,2852.2,2925$ & $\mathrm{~A}, \mathrm{C}$ & $\mathrm{IaA} / \mathrm{Ib}$ & \multirow{2}{*}{$\begin{array}{c}143.0 \text { (C centre) } \\
60.9(\text { A centre }), 134.2(\mathrm{~B} \\
\text { centre })\end{array}$} & 143.0 \\
\hline AD2 & $1172,1288,1361,1650,1976,1851,2919$ & $\mathrm{~A}, \mathrm{~B}^{\prime}, \mathrm{B}$ & IaAB & & 195.1 \\
\hline AD3 & 1650, 1976, 2850, 2919 & A & Ia & 4.5 (A centre) & 4.5 \\
\hline AD4 & $1130,1344,1976$ & $\mathrm{C}$ & $\mathrm{Ib}$ & 10.7 (C centre) & 10.7 \\
\hline AD5 & $1128,1344,1650,1976,2850,2919,3290$ & $\mathrm{C}$ & $\mathrm{Ib}$ & 76.9 (C centre) & 76.9 \\
\hline AD5 & $\begin{array}{c}1130,1284,1344.6,1645,1976.7,2848 \\
2919.7,3201,3394\end{array}$ & $\mathrm{~A}, \mathrm{C}$ & $\mathrm{IaA} / \mathrm{Ib}$ & 23.6 (C centre) & 23.6 \\
\hline AD7 & 1128, 1272, 1344, 1976, 2848, 2921 & $\mathrm{C}$ & $\mathrm{Ib}$ & 393.5 (C centre) & 393.5 \\
\hline AD8 & $1128,1282,1344,1596,1976,2854,2919$ & $A, C$ & $\mathrm{IaA} / \mathrm{Ib}$ & 240.9 (C centre) & 240.9 \\
\hline AD9 & $1344,1645,1976,2848,2919,3191,3394$ & C & $\mathrm{Ib}$ & 137.0 (C centre) & 137.0 \\
\hline AD10 & $1128,1272,1344,1600,1976,2848,2917$ & $\mathrm{C}$ & $\mathrm{Ib}$ & 503.5 (C centre) & 503.5 \\
\hline
\end{tabular}

\subsection{Isotope}

The $C$ isotopic results of microdiamonds are listed in Table 3. The overall range of ${ }^{13} \mathrm{C}$ values in the microdiamonds is between -18.6 and $-21.1 \%$ (Table 3 ).

Table 3. $\delta^{13} \mathrm{C}$ values (\%o) of the microdiamonds.

\begin{tabular}{cc}
\hline Sample ID & $\boldsymbol{\delta}^{\mathbf{1 3}} \mathbf{C} \mathbf{( \% )}$ \\
\hline AD5 & -20.2 \\
AD6 & -19.1 \\
AD7 & -18.6 \\
AD8 & -20.5 \\
AD9 & -21.1 \\
AD10 & -20.6 \\
\hline
\end{tabular}

\section{Discussion}

\subsection{FTIR Spectra of AD Microdiamonds \\ 5.1.1. C-C Absorption Lines}

All the diamond samples showed clear absorptions between 1970 and $2300 \mathrm{~cm}^{-1}$, which were the vibration absorption of C-C, mainly at 1976, 2027 and 2158, among which the absorption at 1976 was the most clear [43]. 


\subsubsection{C-N Absorption Lines}

Natural diamonds are commonly classified according to the presence or absence of nitrogen. Nitrogen is incorporated in the lattice, first as single nitrogen, and then progressively aggregated by natural annealing over time in the sequence of single nitrogen (C centre)-A-aggregate (A centre)-B aggregate (B centre) [44].

In the studied diamonds, A centre $\left(1282 \mathrm{~cm}^{-1}\right)$ was detected in five diamonds, $\mathrm{B}$ centre was detected in one diamond and $\mathrm{C}$-centre was detected in eight diamonds. So, these samples can be classified as type IaA (Figure 2, AD3), IaAB (Figure 2, AD2), IaA/lb (Figure 3), and Ib (Figure 4).

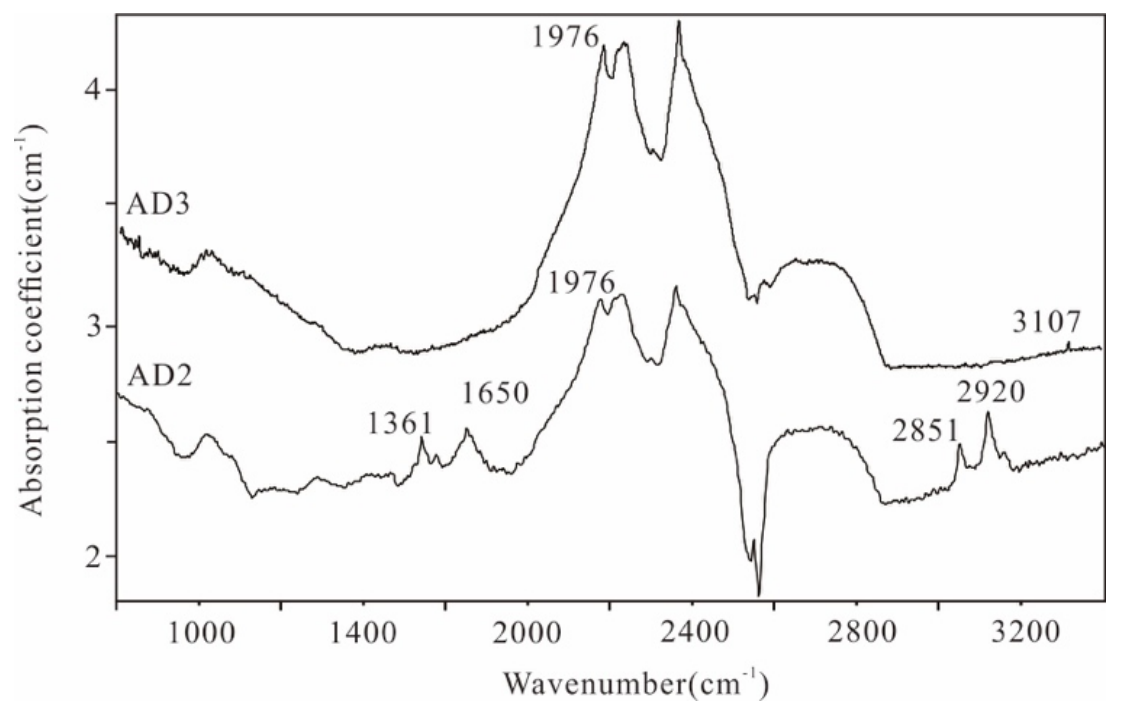

Figure 2. Infrared absorption spectrum collected from diamond AD3 and AD2.

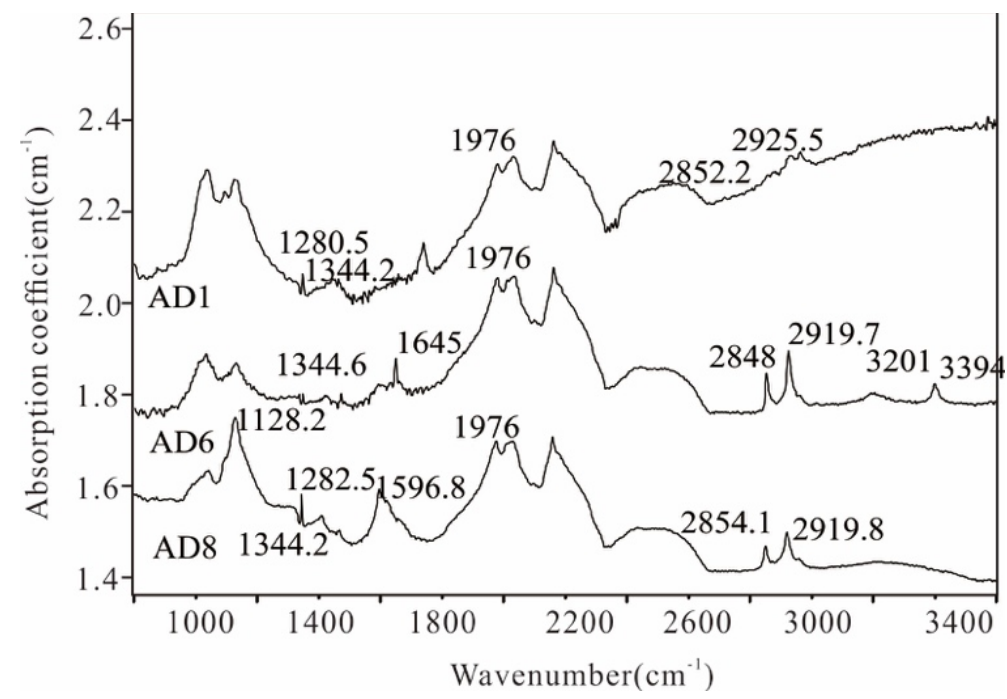

Figure 3. Infrared absorption spectrum collected from diamond AD1, AD6 and AD9 exhibiting both A and C centre. 


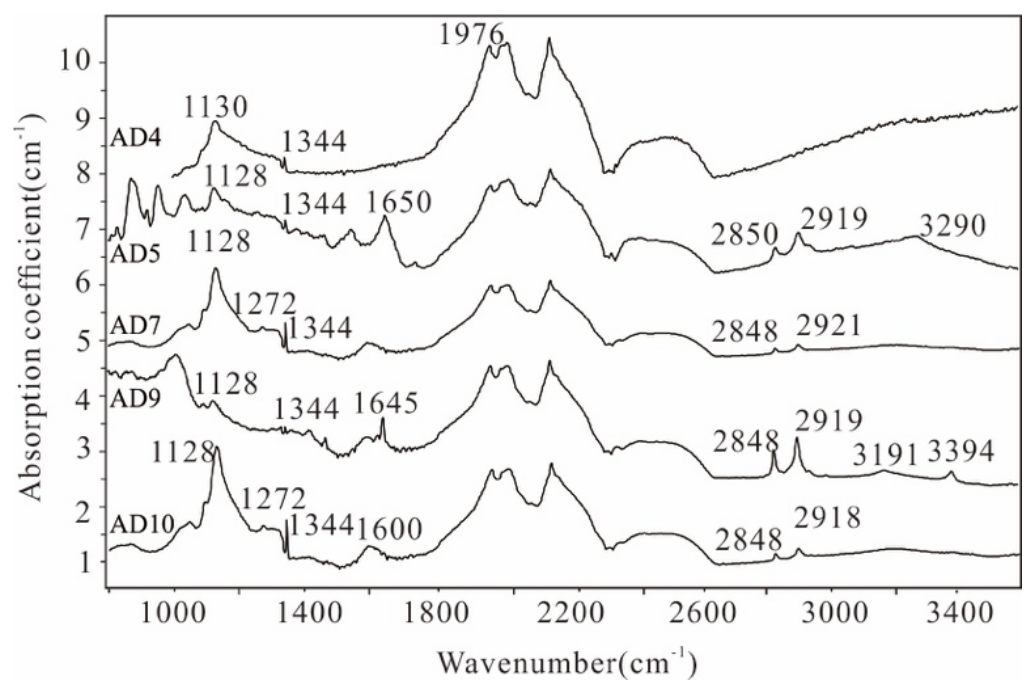

Figure 4. Infrared absorption spectrum collected from diamonds exhibiting $C$ centres.

The eight diamonds are distinctly of type $\mathrm{Ib}$ character and three of the samples contain the $1344 \mathrm{~cm}^{-1}$ single nitrogen absorptions, together with the $1282 \mathrm{~cm}^{-1}$ A-aggregate (Figure 3). However, the di-nitrogen (A centre) abortion was not strong, indicating that the diamonds have low nitrogen conversion rates in the mantle and still retain most of the single nitrogen. This could be attributed to 1) the mantle temperature is relatively low, and/or 2) the mantle residence time is short [45].

Bands or lines corresponding to $\mathrm{B}$ and $\mathrm{B}^{\prime}$ centres were found co-existing in sample $\mathrm{AD} 2$, which is confirmed to be Type IaAB with a total $\mathrm{N}$ concentration of 195 at. ppm and a B centre proportion $\left[100 \mathrm{~N}_{\mathrm{B}} /\left(\mathrm{N}_{\mathrm{B}}+\mathrm{N}_{\mathrm{A}}\right)\right]$ of $68.8 \%$.

\subsection{3. $\mathrm{H}_{2} \mathrm{O}$ and $\mathrm{C}-\mathrm{H}$ Absorption Line}

In these samples, the vast majority of samples showed the absorption of $\mathrm{H}_{2} \mathrm{O}$ at about $1645 \mathrm{~cm}^{-1}$, which was caused by the bending vibration of $\mathrm{H}_{2} \mathrm{O}$ molecule [39]. Meanwhile, many samples also had the symmetric stretching vibration of $\mathrm{H}_{2} \mathrm{O}$ at about $3200 \mathrm{~cm}^{-1}$. However, the antisymmetric stretching vibration absorption of $\mathrm{H}_{2} \mathrm{O}$ around $3630 \mathrm{~cm}^{-1}$ was not detected in these samples.

C-H-related absorption was common in the spectra [39], with typical 2920 and $2850 \mathrm{~cm}^{-1}$ absorption being detected in most samples. The $\mathrm{VN}_{3} \mathrm{H}$ line at $3107 \mathrm{~cm}^{-1}$ was detected in samples AD2 and AD3. The absorption near $3394 \mathrm{~cm}^{-1}$ was detected in some samples, which was related to the $\mathrm{N}-\mathrm{H}$ bond [39].

\subsubsection{Y-Centre}

In this study, Y-centres (Figure 5) were also detected in 4 microdiamonds. The centre is characterized by the dominant asymmetric absorption centred at approximately 1145 to $1150 \mathrm{~cm}^{-1}$. The defect was discovered by Hainschwang (2012) through infrared spectroscopic determination and analysis of a large number of natural and synthetic type $\mathrm{Ib}$ yellow diamonds. The large sampling for that study shows that in natural type $\mathrm{Ib}$ samples from recent diamond productions the Y-centre is very common. So far, the Y-centre has neither been detected in synthetic diamonds, nor in single nitrogen free type Ia diamonds [40]. 


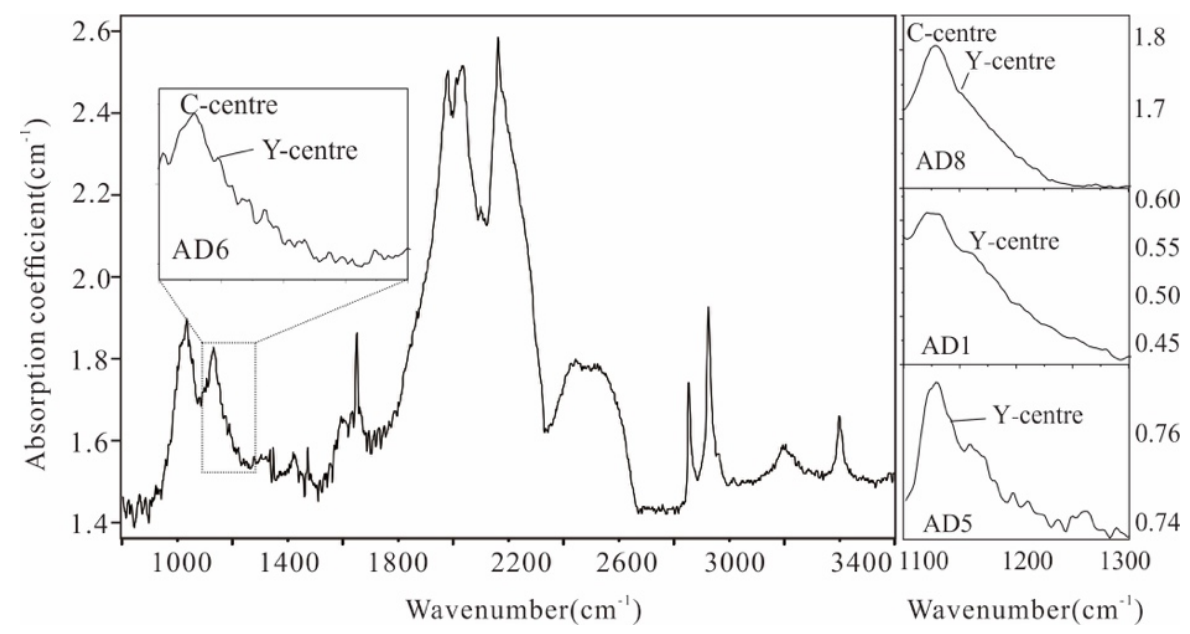

Figure 5. Y-centres in microdiamonds.

Type $\mathrm{Ib}$ diamonds are very rare in nature $(<1 \%$ of cape series yellow diamonds in nature). So far, type $\mathrm{Ib}$ diamonds have only been discovered in Helam/Swartruggens in the eastern block of the Kaapvaal craton [46,47], Lac de Gras in the Slave Craton [48], Dachine in the Amazon Craton [49-51], Orapa rock tubes in the southwest of the Zimbabwe Craton [52], Qilalugaq of the Rae Craton and the Kankan region of the West African Craton [53,54], Tibet of China and Pozanti-Karsanti of Turkey [19].

\subsection{Modelling of Mantle Residence Time}

Modelling mantle residence times for the diamonds requires $\mathrm{N}$ concentration, $\mathrm{N}$ aggregation state and mantle residence temperature as input parameters $[44,55-58]$. The model is also based on the assumption that the total $\mathrm{N}$ concentration of diamond is reflected in the infrared absorption spectrum and that there is a smooth aggregation process from $C$ to $\mathrm{A}$ to $\mathrm{B}$ centres [55]. The requisite nitrogen concentrations and aggregation states were determined via FTIR analyses (see above). The mantle residence temperature was assumed to be in the range of $1200-1225{ }^{\circ} \mathrm{C}$ [33].

The infrared spectra of four points from the core (location 01) to the edge (location 04) of the diamond were determined. According to the analytical results, the content and accumulation degree of $\mathrm{N}$ in diamonds do show spatial variations. The FTIR spectrum of sample AD3 illustrates that the absorption of diamond core was at 1370 and $1175 \mathrm{~cm}^{-1}$ with strong absorption rate, which suggests a IaAB type. However, the absorption rate was weakened as the transition to the edge, where the absorption was mainly at $1282 \mathrm{~cm}^{-1}$, a character of IaA type (Table 4). These characteristics may also reflect the changes of crystallization environment and conditions of diamond with complex structure in different growth stages, or the ability of diamond to capture $\mathrm{N}$. The model ages calculated by $\mathrm{N}$ ranged from $1.29 \mathrm{Ga}$ to $0.74 \mathrm{Ga}$ from the core to edge, so mantle residence time modelled at $1200{ }^{\circ} \mathrm{C}$ is estimated to be $0.55 \mathrm{Ga}$ (Figure 6).

Table 4. Calculation of $\mathrm{N}$ concentration and $t_{\mathrm{MR}}$.

\begin{tabular}{|c|c|c|c|c|}
\hline Location & $\mathbf{N}_{\mathrm{A}} / \mathrm{ppm}$ & $\mathrm{N}_{\mathrm{B}} / \mathrm{ppm}$ & \multirow{2}{*}{$\begin{array}{c}\mathrm{N}_{\mathrm{T}} \\
\left(\times 10^{-6}\right)\end{array}$} & \multirow[t]{2}{*}{ Modelling Age/Ga } \\
\hline & $\left(\sim 1282 \mathrm{~cm}^{-1}\right)$ & $\mathrm{N}_{\mathrm{B}}\left(\sim 1175 \mathrm{~cm}^{-1}\right)$ & & \\
\hline 01 & 41.590 & 56.615 & 98.205 & 1.29 \\
\hline 02 & 58.767 & 71.982 & 130.750 & 0.87 \\
\hline 03 & 56.229 & 59.316 & 115.545 & 0.85 \\
\hline 04 & 74.587 & 109.528 & 184.115 & 0.74 \\
\hline
\end{tabular}




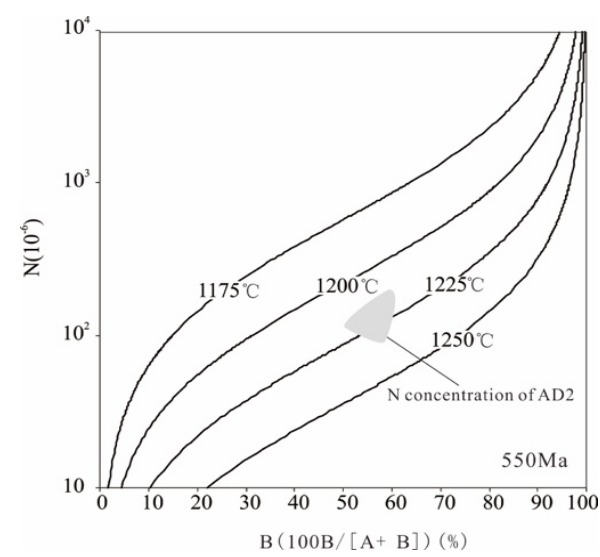

Figure 6. Nitrogen content plotted against the percentage of $B(100 B /[A+B])$ aggregation in $550 \mathrm{Ma}$ for Type IaAB diamonds $[37,59]$.

\subsection{Isotope}

Carbon isotopic compositions of diamonds from kimberlite, lamproite and metamorphic rocks have been extensively studied [23,49,60-62]. According to Cartigny (2005), eclogitic diamonds (E-type) have $\delta^{13} \mathrm{C}$ ranging from -38.5 to $+2.7 \%$ and peridotitic diamonds have $\delta^{13} \mathrm{C}$ from -26.4 to $+0.2 \%$. Despite the different $\delta^{13} \mathrm{C}$ ranges between eclogitic and peridotitic diamonds, both groups of diamonds are characterized by a mode at $\delta^{13} \mathrm{C}$ $\sim-5 \%$, which is consistent with the mantle range of carbon isotopic composition [62]. Ultra-high pressure (UHP) metamorphic diamonds mainly have $\delta^{13} \mathrm{C}$ out of the normal mantle range [9,62]. Diamonds from alkalic dolerites studied here are all characterized by low $\delta^{13} \mathrm{C}$ values with a narrow range (Figure 7). These low $\delta^{13} \mathrm{C}$ values of doleriteshosted diamonds overlap with the lower ends of peridotitic diamonds and metamorphic diamonds, and the upper end of the ophiolitic diamonds.

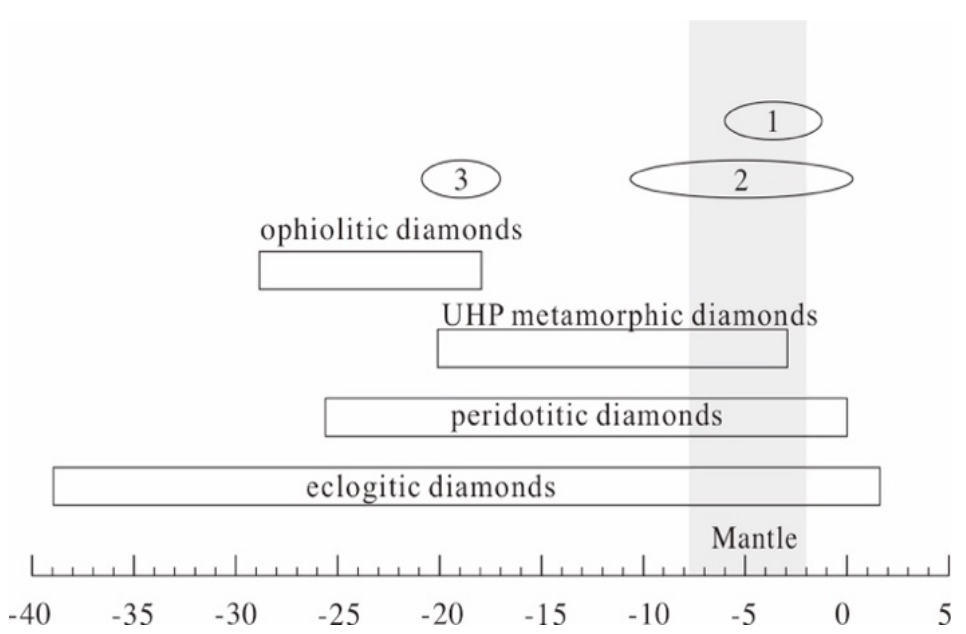

Figure 7. Comparative Column of $\delta^{13} \mathrm{C}$ values (modified from Cartigny (2005)). 1-Macro-diamonds from North China Craton; 2-Macro-diamonds from Yangtze Craton; 3-microdiamonds in Alkalic dolerites.

\section{Conclusions}

In the past, many deposits of macro-diamonds, mostly of type Ia or IIa, were found in the North China Craton, and they have been extensively studied. Microdiamonds which were recovered from the alkalic dolerites of the North China Craton were studied by FTIR and Carbon isotopic.

These diamonds are similar in colour and shape to ophiolite type diamonds and show different characteristics of kimberlite and lamproite diamonds. These diamonds are 
usually light yellow to yellow, with a few colourless, and cubic, octahedral or rhomboidal dodecahedron, and octahedron in shape. The surface characteristics of diamonds, such as dissolution, can be observed. The overall $\mathrm{N}$ concentration is not high, with an average of $173 \mathrm{ppm}$. The infrared spectra show that most of these diamonds were type $\mathrm{Ib}$, and $C$ centres were found at $1344 \mathrm{~cm}^{-1}$ in these diamonds. Three diamonds of our samples are classified as Type $\mathrm{Ia} / \mathrm{Ib}$, because of $\mathrm{A}$ centres and $\mathrm{C}$ centres in these diamonds. Two diamonds are classified as type IaAB because $B, B^{\prime}$ and $A$ centres were found co-existing. FTIR microscopic measurements from the core to the edge of the type IaAB diamond suggest a mantle residence time of approximately $550 \mathrm{Ma}$. The $\mathrm{C}$ isotopic analysis reveals that these diamonds are strongly depleted in ${ }^{13} \mathrm{C}$. These low $\delta^{13} \mathrm{C}$ values of doleriteshosted diamonds overlap with the lower ends of peridotitic diamonds and metamorphic diamonds, and the upper end of the ophiolitic diamonds. Additionally, the reason for the strong deficit $\delta^{13} \mathrm{C}$ shown by the carbon isotope should be studied in the future.

Author Contributions: Methodology, J.Y. and L.L.; formal analysis, Y.C., L.L. and K.L.; investigation, Y.C., J.Y. and F.L.; writing-original draft preparation, Y.C. and Z.C.; writing-review and editing, Y.C., L.L. and K.L.; supervision, J.Y.; project administration, Y.C. All authors have read and agreed to the published version of the manuscript.

Funding: This research was funded by Natural Science Foundation of Jiangsu Province, China, grant number BK20191132, National Natural Science Foundation of China, grant number 41402075 and Project of China Geological Survey, grant number DD20190513.

Data Availability Statement: The data presented in this study are available in this article.

Acknowledgments: The authors thank the second Institute of Hydrology and Engineering Geological Prospecting of Anhui Geological Prospecting Bureau, and No. 5 Geological Team of Jiangsu Geology and Mineral Bureau for the generous provision of diamonds for this study. Without the help of Yuguang Ma, Zhongdou Dong, Jianbin Shi and this study would not have been possible. The authors also thanks Thomas Stachel, Meiyan Lai and Jiqiang Liu for their help in infrared spectrum testing. We thank reviewers and editor for constructive comments that greatly improved the paper.

Conflicts of Interest: The funders had no role in the design of the study; in the collection, analyses, or interpretation of data; in the writing of the manuscript, or in the decision to publish the results.

\section{References}

1. Zhang, P. Actively explore a new type diamond primary deposit. Manag. Geol. Sci. Technol. 1998, 15, 1-8.

2. Zhang, P. New knowledge of some important questions about diamond deposit genesis. Hunan Geol. 1998, 17, $204-210$.

3. Tappert, R.; Tappert, M.C. The Morphology of Diamonds. In Diamonds in Nature; Springer: Berlin/Heidelberg, Germany; GmbH \& Co. K: Berlin, Germany, 2011; pp. 13-22.

4. Tappert, R.; Tappert, M.C. The Origin of Diamonds. In Diamonds in Nature; Springer: Berlin/Heidelberg, Germany; GmbH \& Co. K: Berlin, Germany, 2011; pp. 1-14.

5. Murphy, K. Diamond Pipeline; SNL Metals Economics Group: Halifax, NS, Canada, 2014; pp. 1-13.

6. Fedortchouk, Y.; McIsaac, E. Surface Dissolution Features on Kimberlitic Chromites as Indicators of Magmatic Fluid and Diamond Quality. In Proceedings of the 10th International Kimberlite Conference, Bangalore, India, 5-11 February 2012; pp. $297-308$.

7. Hutchison, M.T. In Diamond Exploration and Regional Prospectivity of the Northern Territory of Australia. In Proceedings of the 10th International Kimberlite Conference, Bangalore, India, 5-11 February 2012; Springer: New Delhi, India, 2013 ; pp. $257-280$.

8. Kogarko, L.N.; Ryabchikov, I.D. Diamond potential versus oxygen regime of carbonatites. Petrology 2013, 21, 316-335. [CrossRef]

9. Ogasawara, Y. Microdiamonds in ultrahigh-pressure metamorphic rocks. Elements 2005, 1, 91-96. [CrossRef]

10. Yang, J.; Xu, Z.; Dobrzhinetskaya, L.F.; Green, H.W.; Pei, X.; Shi, R.; Wu, C.; Wooden, J.L.; Zhang, J.; Wan, Y. Discovery of metamorphic diamonds in central China: An indication of a $>4000-\mathrm{km}$-long zone of deep subduction resulting from multiple continental collisions. Terra Nova 2003, 15, 370-379. [CrossRef]

11. Huss, G.R. Meteoritic nanodiamonds: Messengers from the stars. Elements 2005, 1, 97-100. [CrossRef]

12. Tappert, R.; Foden, J.; Stachel, T.; Muehlenbachs, K. Deep mantle diamonds from South Australia: A record of Pacific subduction at the Gondwanan margin. Geology 2009, 37, 43-46. [CrossRef]

13. Yang, J.; Xu, X.; Li, Y.; Li, J.; Ba, D.; Rong, H.; Zhang, Z. Diamonds recovered from peridotite of the Purang ophiolite in the Yarlung-Zangbo suture of Tibet: A proposal for a new type of diamond occurrence. Acta Petrol. Sin. 2012, 27, 3171-3178.

14. Yang, J.; Xu, X.; Bai, W.; Zhang, Z.; Rong, H. Features of diamond in ophiolite. Acta Petrol. Sin. 2014, 30, 2113-2124.

15. Rong, H.; Yang, J.; Zhang, Z.; Xu, X. A preliminary study of FT-IR on the diamonds from the Luobusa chromitites of Tibet and the eclogite of CCSD-MH, China. Acta Petrol. Sin. 2013, 029, 1861-1866. 
16. Yang, J.; Wu, W.; Lian, D.; Rui, H. Peridotites, chromitites and diamonds in ophiolites. Nat. Rev. Earth Environ. 2021, 2, 198-212. [CrossRef]

17. Cai, Y.; Zhang, J.; Dong, Z.; Cao, Z.; Xiao, S.; Li, S.; Li, C.; Chen, L.; Fan, F. Neoproterozoic basic magmatism in the north of Anhui Province: Evidence from whole-rock geochemistry and U-Pb geochronology of Diabase in Langan area. Geol. China 2018, 45, 351-366.

18. Zhang, J.; Cai, Y.; Dong, Z.; Ma, Y.; Fan, F.; Chen, L.; Li, C.; Yang, D. Investigation on Mineral Characteristic of Diamond and Geochemical Characteristic of its host in the Langan Area, Anhui Province. J. Gems Gemmol. 2015, 17, 1-11.

19. Lian, D.; Yang, J. Ophiolite-Hosted Diamond: A New Window for Probing Carbon Cycling in the Deep Mantle. Engineering 2019, 5, 406-420. [CrossRef]

20. Cai, Y.; Yang, X.; Kang, C. Understanding of the present study of the diamond at domestic and overseas. East China Geol. 2017, 38, 95-102.

21. Wang, X.; Xiao, Y.; Sun, H.; Wang, Y.; Liu, J.; Yang, K.; Gu, H.; Hou, Z.; Tian, Y.; Wu, W.; et al. Initiation of the North China Craton destruction: Constraints from the diamond-bearing alkaline basalts from Lan'gan, China. Gondwana Res. 2020, 80, 228-243. [CrossRef]

22. Yang, J.; Simakov, S.K.; Moe, K.; Scribano, V.; Lian, D.; Wu, W. Comment on "Comparison of enigmatic diamonds from the Tolbachik arc volcano (Kamchatka) and Tibetan ophiolites: Assessing the role of contamination by synthetic materials" by Litasov et al. 2019. Gondwana Res. 2020, 79, 301-303. [CrossRef]

23. Lian, D.; Yang, J.; Wiedenbeck, M.; Dilek, Y.; Rocholl, A.; Wu, W. Carbon and nitrogen isotope, and mineral inclusion studies on the diamonds from the Pozanti-Karsanti chromitite, Turkey. Contrib. Mineral. Petrol. 2018, 173, 72. [CrossRef]

24. Howell, D.; Griffin, W.L.; Yang, J.; Gain, S.; Stern, R.A.; Huang, J.; Jacob, D.E.; Xu, X.; Stokes, A.J.; O’Reilly, S.Y. Diamonds in ophiolites: Contamination or a new diamond growth environment? Earth Planet. Sci. Lett. 2015, 430, 284-295. [CrossRef]

25. Cai, Y.; Xu, M.; Shi, J.; Yang, X.; Zhang, J.; Kang, C.; Cao, Z.; Dong, Z.; Ma, Y. Mineral chemistry characteristics of clinopyroxene and ilmenite in basite of Langan area, northern Anhui Province. Geol. Bull. China 2019, 38, 1-13.

26. Cai, Y.; Zhang, J.; Kang, C.; Yang, X.; Cao, Z.; Dong, Z.; Ma, Y.; Shi, J. Mineral chemistry characteristics of garnets in diamondiferous basite of Langan area, Anhui Province. Geol. Bull. China 2019, 38, 18-28.

27. Zhang, J.; Lu, F.; Cai, Y. Characteristic of alkali-basic rock type diamond ore's Remote Sensing in the Langan area, Anhui province. J. Gems Gemmol. 2016, 19, 1-9.

28. Cai, Y.; Chen, G.; Zhang, J.; Dong, Z.; Zhou, S. Geochemical features of the olivine-gabbros and its relationship with diamondforming in the Langan area, Anhui province. Resour. Surv. Environ. 2014, 35, 245-253.

29. Zhuang, J. Study of magnetic anomaly features and its implications for diamond exploration in the Langan-Chualan area, Suzhou City. Geol. Anhui 2013, 23, 123-125.

30. Cai, Y.; Shi, J.; Zhou, Q.; Xu, M.; Zhang, J.; Zhang, X.; Yuan, Q. Study on the Geochemistry of the Diamondiferous Olivine Basalt and Magma Evolution in Bailushan area, Xuzhou. China Geol. 2020. Available online: https://kns.cnki.net/kcms/detail/11.1167. P.20200507.1415.004.html (accessed on 7 May 2020).

31. Yang, J.; Dobrzhinetskaya, L.; Bai, W.; Fang, Q.; Robinson, P.T.; Zhang, J.; Green, H.W. Diamond and coesite-bearing chromitites from the Luobusa ophiolite, Tibet. Geology 2007, 35, 875-878. [CrossRef]

32. Zhang, H.; Yang, Y. Emplacement age and Sr-Nd-Hf isotopic characteristics of the diamondiferous kimberlites from the eastern North China Craton. Acta Petrol. Sin. 2007, 23, 285-294.

33. Chen, H.; Qiu, Z.; Lu, T.; Richard, S.; Thomas, S.; Sun, Y.; Zhang, J.; Ke, J.; Peng, S.; Qin, S. Variations in carbon isotopic composition in the subcontinental lithospheric mantle beneath the Yangtze and North China Cratons: Evidence from in-situ analysis of diamonds using SIMS. China Sci. Bull. 2013, 58, 355-364. [CrossRef]

34. Zhao, G.; Wilde, S.A.; Cawood, P.A.; Lu, L. Thermal evolution of two textural types of mafic granulites in the North China craton: Evidence for both mantle plume and collisional tectonics. Geol. Mag. 1999, 136, 223-240. [CrossRef]

35. Lu, F.; Zheng, J.; Chen, M. Discussion on Formation Condition of Diamonds. Earth Sci. Front. 1998, 5, $125-132$.

36. Lai, M.Y.; Stachel, T.; Breeding, C.M.; Stern, R.A. Yellow diamonds with colourless cores-Evidence for episodic diamond growth beneath Chidliak and the Ekati Mine, Canada. Miner. Petrol. 2020, 114, 91-103. [CrossRef]

37. Howell, D.; O’Neill, C.J.; Grant, K.J.; Griffin, W.L.; Pearson, N.J.; O'Reilly, S.Y. $\mu$-FTIR mapping: Distribution of impurities in different types of diamond growth. Diam. Relat. Mater. 2012, 29, 29-36. [CrossRef]

38. Li, K.; Li, L.; Pearson, D.G.; Stachel, T. Diamond isotope compositions indicate altered igneous oceanic crust dominates deep carbon recycling. Earth Planet. Sci. Lett. 2019, 516, 190-201. [CrossRef]

39. Howell, D.; Weiss, Y.; Smit, K.V.; Loudin, L.; Nestola, F. In DiaMap: New applications for processing IR spectra of fluid-rich diamonds and mapping diamonds containing isolated nitrogen (Type Ib) and boron (Type IIb). In Proceedings of the 11th International Kimberlite Conference, Gaborone, Botswana, 18-22 September 2017; Spring: Gaborone, Botswana, 2017.

40. Hainschwang, T.; Fritsch, E.; Notari, F.; Rondeau, B. A new defect center in type Ib diamond inducing one phonon infrared absorption: The Y center. Diam. Relat. Mater. 2012, 21, 120-126. [CrossRef]

41. Lai, M.Y.; Breeding, C.M.; Stachel, T.; Stern, R.A. Spectroscopic features of natural and HPHT-treated yellow diamonds. Diam. Relat. Mater. 2020, 101, 107642. [CrossRef]

42. Liggins, S. Identification of point defects in treated single crystal diamond. Ph.D Thesis, University of Warwick, Coventry, UK, 2010. 
43. Sun, Y.; Qiu, Z.; Lu, T.; Chen, H.; Chen, B.; Peng, S.; Wei, R.; Li, L. Micro-FTIR Mapping Tracer for the Heterogeneity Growth of Nitrogen Impurities in Natural Diamond from Three Localities in China. Spectrosc. Spectr. Anal. 2012, 32, $2070-2074$.

44. Davies, G. Decomposing the IR absorption spectra of diamonds. Nature 1981, 290, 40-41. [CrossRef]

45. Davies, G. The A nitrogen aggregate in diamond-its symmetry and possible structure. J. Phys. C Solid State Phys. 1976, 9, L537-L542. [CrossRef]

46. Logan, F. A Mineralogical and Isotope Study of Macrodiamonds from the Helam Mine. Honors Thesis, Queens University, Belfast, South Africa, 1999.

47. Mc Kenna, N.; Gurney, J.J.; Klump, J.; Davidson, J.M. Aspects of Diamond Mineralisation and Distribution at the Helam Mine, South Africa. Lithos 2004, 77, 193-208. [CrossRef]

48. Davies, R.M.; Griffin, W.L.; O'Reilly, S.Y.; Doyle, B.J. Mineral inclusions and geochemical characteristics of microdiamonds from the DO27, A154, A21, A418, DO18, DD17 and Ranch Lake kimberlites at Lac de Gras, Slave Craton, Canada. Lithos 2004, 77, 39-55. [CrossRef]

49. Cartigny, P. Mantle-related carbonados? Geochemical insights from diamonds from the Dachine komatiite (French Guiana). Earth Planet. Sci. Lett. 2010, 296, 329-339. [CrossRef]

50. Smit, K.V.; Shirey, S.B.; Richardson, S.H.; le Roex, A.P.; Gurney, J.J. Re-Os isotopic composition of peridotitic sulphide inclusions in diamonds from Ellendale, Australia: Age constraints on Kimberley cratonic lithosphere. Geochim. Cosmochim. Acta 2010, 74, 3292-3306. [CrossRef]

51. Smith, C.B.; Walter, M.J.; Bulanova, G.P.; Mikhail, S.; Burnham, A.D.; Gobbo, L.; Kohn, S.C. Diamonds from Dachine, French Guiana: A unique record of Early Proterozoic subduction. Lithos 2016, 265, 82-95. [CrossRef]

52. Timmerman, S.; Koornneef, J.M.; Chinn, I.L.; Davies, G.R. Dated eclogitic diamond growth zones reveal variable recycling of crustal carbon through time. Earth Planet. Sci. Lett. 2017, 463, 178-188. [CrossRef]

53. Weiss, K.; De Floriani, L. Diamond Hierarchies of Arbitrary Dimension. Comput. Graph. Forum 2009, 28, 1289-1300. [CrossRef]

54. Weiss, Y.; Kessel, R.; Griffin, W.L.; Kiflawi, I.; Klein-BenDavid, O.; Bell, D.R.; Harris, J.W.; Navon, O. A new model for the evolution of diamond-forming fluids: Evidence from microinclusion-bearing diamonds from Kankan, Guinea. Lithos 2009, 112, 660-674. [CrossRef]

55. Allen, B.P.; Evans, T. Aggregation of Nitrogen in Diamond, Including Platelet Formation. Math. Phys. Sci. 1981, 375, 93-104.

56. Clark, C.D.; Davey, S.T. One-phonon infrared absorption in diamond. J. Phys. C Solid State Phys. 1984, 17, 1127. [CrossRef]

57. Chen, M.; Li, Y.; Di, J.; Lu, F.; Zheng, J. Agate-like Structure and Heterogeneities of Nitrogen and Hydrogen Impurities of Diamond in Mengyin, China. Acta Geol. Sin. 2006, 80, 1197-1201.

58. Chen, M.; Lu, F.; Di, J.; Zheng, J. Cathodoluminescence and Infrared Spectroscopy of Wafangdian Diamond in Liaoning Province. Chin. Sci. Bull. 2000, 45, 1424-1428.

59. Howell, D.; O Neill, C.; Grant, K.; Griffin, W.; O Reilly, S.; Pearson, N.; Stern, R.; Stachel, T. Platelet development in cuboid diamonds: Insights from micro-FTIR mapping. Mineral. Petrol. 2012, 164, 1011-1025. [CrossRef]

60. Shirey, S.B.; Cartigny, P.; Frost, D.J.; Keshav, S.; Nestola, F.; Nimis, P.; Pearson, D.G.; Sobolev, N.V.; Walter, M.J. Diamonds and the geology of mantle carbon. Rev. Mineral. Geochem. 2013, 75, 355-421. [CrossRef]

61. Palot, M.; Cartigny, P.; Harris, J.W.; Kaminsky, F.V.; Stachel, T. Evidence for deep mantle convection and primordial heterogeneity from nitrogen and carbon stable isotopes in diamond. Earth Planet. Sci. Lett. 2012, 357, 179-193. [CrossRef]

62. Cartigny, P. Stable isotopes and the origin of diamond. Elements 2005, 1, 79-84. [CrossRef] 